\title{
Ecological Compensation Standards of Wetland Restoration Projects
}

\author{
Jia $\mathrm{He}^{1}$, Junyong Ai ${ }^{1}$, Xiaodong $\mathrm{Zhu}^{1 *}$, Xiang Sun ${ }^{2 * *}$ \\ 'State Key Laboratory of Pollution Control and Resources Reuse, School of the Environment, \\ Nanjing University, 210023, Nanjing, People's Republic of China \\ ${ }^{2}$ School of Environment, Guangxi University, 530004 Nanning, People's Republic of China
}

Received: February 9, 2015

Accepted: June 21, 2015

\begin{abstract}
Establishing a framework for evaluating the ecological compensation standard (ECS) of wetland restoration projects (WRPs) is significant for providing scientific support for sustainable conservation of wetland systems and guiding financial collection from various aspects. In this study, the complex framework for evaluating the ECS of WRPs I (with wetland park) and WRPs II (without wetland park) was developed. In addition to the same index of cost-benefit for WRPs I and II, the effect of increasing housing prices in the surrounding areas of a wetland is an additional consideration for WRPs I. By comparing the construction and daily management costs of wastewater treatment plants (WWTPs) with the costs of WRPs, and using the contingent valuation method (CVM), the environmental benefit of WRPs and public WWTPs were obtained. This framework was applied to 10 WRPs within Taihu Lake Basin, China. The results showed that the WWTP for WRPs I and II were $2.09 \cdot 10^{4} \mathrm{USD} \cdot \mathrm{ha}^{-1} \cdot \mathrm{yr}^{-1}$ and $1.82 \cdot 10^{4} \mathrm{USD} \cdot \mathrm{ha}^{-1} \cdot \mathrm{yr}^{-1}$, respectively. Considering the land-transferring fees of the surrounding area of WRPs I, subsidies from the government can be according to the compensation standard of WRPs II. Thus, if the public willingness to pay for supporting WRPs can be implemented in reality, the government need not pay extra compensation for WRPs. In the absence of a public WWTP, the government only needs to pay WRPs II $0.08 \cdot 10^{4} \mathrm{USD} \cdot \mathrm{ha}^{-1} \cdot \mathrm{yr}^{-1}$ to ensure the construction and operation of WRPs II and I. With the help of ECS established in this study, decision makers can obtain a differentiated compensation standard by incorporating reward and punishment mechanisms. By analyzing the cost and benefit of WRPs, the approaches for increasing capital sources of ecological compensation for WRPs were recommended, including improvement in public awareness of the wetland ecosystem services, capturing the public WTP, ticketing wetland park entries, land-transferring fees, and the integration of the above methods.
\end{abstract}

Keywords: cost-benefit analysis, willingness to pay, wetland restoration projects, waste water treatment plants, land-transferring fees

\section{Introduction}

As one of the most important ecosystems, wetlands provide various services to society, such as water purification, habitat provision, flood detention, and biodiversity conser-

*e-mail:xdzhu@nju.edu.cn

**e-mail: sunxiang@nju.edu.cn vation [1-3]. These services are critical to human survival and well-being. Unfortunately, rapid population growth and urbanization in China has resulted in the deterioration of wetland ecosystems and the environment [4, 5]. Facing this threat, some conservation scientists, governmental agencies, and international conservation groups think that wetland restoration projects (WRPs) is an appropriate way to mitigate the ongoing degradation of wetland ecosystems 
$[6,7]$. As a public service, government support was expected to be a significant actor to underpin WRPs' establishment and operation [8]. However, in China the national and local financial investment on WRPs is so insufficient that it seriously affects the normal operation and conservation of the WRPs. To ensure the effective protection and sustainable development of wetland ecosystems in China, government agencies such as the National Development and Reform Commission (NDRC) have drafted The Ordinance of Ecological Compensation and Several opinions on establishing perfect ecological compensation mechanism in 2011. The basic ideas are to increase subsides for protection of wetlands and establish an ecological compensation mechanism for rewarding excellence and punishing the subpar (NDRC, 2011).

There is substantial literature on ecological compensation and the ecological compensation standard (ECS), which are related to compensation effect and feasibility as the foundation for ecological compensation [9]. At present, ECS always is determined by evaluating these following values:

1) investment and opportunity cost of those preservers,

2) benefits of those beneficiaries,

3) loss value due to these ecosystems damage,

4) value of ecosystem services [10].

In the United States and European Union (EU), the compensation standards are calculated based on the opportunity cost of agricultural crops of local farmers [11]. MacMillan et al. estimated the costs of damage due to goose grazing to farmers, and conservation benefits using the contingent valuation method (CVM) [12]. This can be seen as providing a standard for the government compensating farmers in goose areas in order to further conservation.

Due to under-maintenance and lack of funds for operation in many water supply systems, Kanayo et al. applied the CVM to identify peoples' willingness to pay (WTP) for an improved water supply in Nsukka, ascertain what they would pay to support the government, and determine the amount of revenue that the government could generate [13]. In China, Xie et al. determined the compensation standard in multi-district river networks based on the treatment costs of sewage in north Jiangsu Province [14]. Xiong and Wang evaluated the benefit losses of the resettled farmers and the increased values of ecosystem service caused by wetland recovery, and the ECS for relocated farmers was calculated by considering the combination of the farmers' compensation appeal [15]. Rao et al. developed the marine ecological damage compensation (MEDC) standard considering spatial variation in ecological services and the damage degree to ecosystems by different human activities [16]. In contrast, little attention has been paid to the differentiated ECS annually according to performance evaluation, especially for WRPs $[7,16]$.

Although some countries have implemented wetland ecological compensation over the past two decades, such as the Clean Water Act and wetland mitigation banking in the U.S., the practice of wetland ecological compensation in China started relatively late. In The Ordinance of Ecological Compensation (drafted by the NDRC in 2011), the wetland ecosystem was first put into the fields of ecological compensation [17-19]. Additionally, many WRPs are not sustainable because of the failure to recover costs and lack of funds for operation. Thus, it is urgently needed to establish an appropriate ECS that provides financial support for wetland construction and normal operation and is easy for local governments to implement.

Taihu Lake, the third largest freshwater lake in China, is located in the lower reaches of the Yangtze River and has a surface area of approximately $2,338 \mathrm{~km}^{2}$, a mean depth of $2.1 \mathrm{~m}$, a volume of 4.4 billion $\mathrm{m}^{3}$, and a catchment area of $36,500 \mathrm{~km}^{2}$ [20]. As a densely populated area, the basin is economically vital to its fast growth. Although it accounts for only $0.4 \%$ of the total area of China and $2.9 \%$ of the nation's population, it provides more than $14 \%$ of China's gross domestic product (GDP) [21]. The lake is a key drinking water source for the locals (estimated to be 10 million), and serves important economic functions such as tourism, fisheries, and shipping. Ironically, the lake is also a repository for waste from urban centers and nearby agricultural and industrial segments [22]. The lake has been seriously polluted, and the wetland ecosystems of Taihu Lake basin (TLB) have been heavily fragmented and degraded. In late May 2007 a massive bloom of toxin-producing cyano bacteria in Taihu Lake triggered a wide range of public concern about the serious environmental pollution issues and ecological degradation of Taihu Lake.

In order to restore the degrading aquatic ecosystem services in Taihu Lake, the government conducted a series of WRPs in 2008-11 and planned to build more in the future [7]. However, a shortage of financial funds will exist for a long period of time; financial pressures are expected to grow. The governments increasingly hope that the public can participate in wetland conservation. And, because of the performances achieved by these WRPs showed a significant variation, the unified compensation standard clearly does not apply in the future. Thus, governments urgently need to know the differentiated ECS to ensure a reasonable allocation of subsidies and long-term stable operation of WRPs.

In this study, a framework for evaluation of ECS was developed in the case of 10 WRPs in TLB to mainly address the following issues:

1) how much are the baselines of ECS of WRPs I (WRPs with wetland park) and WRPs II (WRPs without wetland park),

2) implications of differentiated compensation standards on performance of WRPs,

3) proposing approaches for collecting funds for wetland ecological compensation.

\section{Materials and Methods}

\section{Study Area}

We chose Wuxi City of Jiangsu Province of China as our study area. It covers an area of $4,627 \mathrm{~km}^{2}$ and is located in the northeastern part of Taihu Lake. It is one of the most economically developed areas in China with quickly 
Table 1. Status of studied WRPs.

\begin{tabular}{|c|c|c|c|c|}
\hline \multicolumn{2}{|r|}{ WRPs } & Location & Land cover (ha) & Construction schedule \\
\hline \multirow{5}{*}{ WRPs I } & Shangxianhe Wetland & Binhu District & 79 & $2008-10$ \\
\hline & Changguangxi Wetland & Binhu District & 152 & $2008-10$ \\
\hline & Lianghong Wetland & Binhu District & 89 & $2008-09$ \\
\hline & Guansheshan Wetland & Binhu District & 38 & $2008-10$ \\
\hline & Shibawan Lakeside Wetland & Binhu District & 265 & $2008-09$ \\
\hline \multicolumn{3}{|l|}{ Mean } & 125 & \\
\hline \multirow{5}{*}{ WRPs II } & Daxigang Estuary Wetland & Binhu District & 53 & $2008-09$ \\
\hline & Taihu Lake Shore Wetland & Yixing City & 76 & $2008-09$ \\
\hline & Dapugang Wetland & Yixing City & 15 & 2008-09 \\
\hline & Lianghewan Wetland & Binhu District & 195 & $2008-10$ \\
\hline & Jiulihe Wetland & Xishan District & 47 & $2010-11$ \\
\hline \multicolumn{3}{|l|}{ Mean } & 77 & \\
\hline
\end{tabular}

developing industrialization and urbanization. As Taihu Lake was Wuxi's sole water source, the pollution in Taihu caused by rapid growth in wastewater discharges from TLB has inevitably affected the safety of the water supply for Wuxi [7]. The algal bloom that occurred in Taihu Lake triggered a severe drinking water crisis in Wuxi in summer 2007 that was sensationalized in a News Focus story, which was reported later in the journal Science [23, 24].

Wuxi has been named the most environmentally sensitive area in TLB and also firstly conducted a series of WRPs to improve water quality and restore the degraded aquatic wetland ecosystem in Taihu [7]. However, for a long time some of the local governments in China attached great importance to construction and ignored management, so that some WRPs have stalled or low efficiency due to shortages of follow-up funds. In order to ensure sustainable development of WRPs, the Joint Suggestions on Strengthening Wetland Ecological Protection of Taihu Lake Basin were jointly promulgated by the People's Political Consultative Conference of Wuxi, Suzhou, Changzhou, Jinxing, and Huzhou in 2012, which called for the implementation of ecological compensation for wetland ecosystems.

In this study, 10 major WRPs in Wuxi (Table 1, Fig. 1) were selected for assessing the ECS of the WRPs in the TLB. These WRPs were divided into two classes according to whether they covered a wetland park or not: WRPs I and II [7].

\section{Research Hypotheses and Framework}

The ecological compensation mechanism for wetland conservation has been paid attention gradually in China. However, there is a great gap between the theoretical research and practical application, and there are still many pressing problems, such as how to establish and calculate the ECS [10]. Currently, there were a large number of studies has focused on the quantitative evaluation of ecological compensation, mainly targeting benefits, costs, and benefitto-cost ratios [25]. However, due to lots of benefits (or ecosystem service values) such as the fact that water resource regulation and climate regulation cannot be traded in the real market, there is a huge gap between the evaluated values and compensation capacity. The evaluation result only was considered as theoretical ceiling values for compensation. Thus, for environmental benefits of implementing WRPs, the value of waste treatment is only considered, which has proven to be the main ecological service of wetlands [26-28]. Furthermore, for the performance of the WRPs, the main concern of the local governments is whether the water quality improved, which is also the issue that needs to be addressed urgently after the drinking water crisis in Taihu.

Public WTPs play a vital role in wetland conservation activities. Wetland parks were established in order to encourage more public participation in the conservation of wetlands by improving the wetland environment and providing recreational, aesthetic, and educational services to the public. We also assumed that the public WTP is a fixed value over the next five years, although their WTP might change with the effect of wetland conservation. Moreover, wetland parks were established in order to encourage more public participation in the conservation of wetland. Compared to WRP Class II, Class I was usually built with aesthetics in mind for attracting visitors. The construction of Class I also could stimulate the surrounding land values of wetland parks [7, 29].

Based on the hypothesis above, we described a framework for the development of an ECS with an application to Wuxi City, based on the general method to calculate the ECS, such as the public WTP and the cost-benefit analysis of implementing WRPs (Fig. 2). 


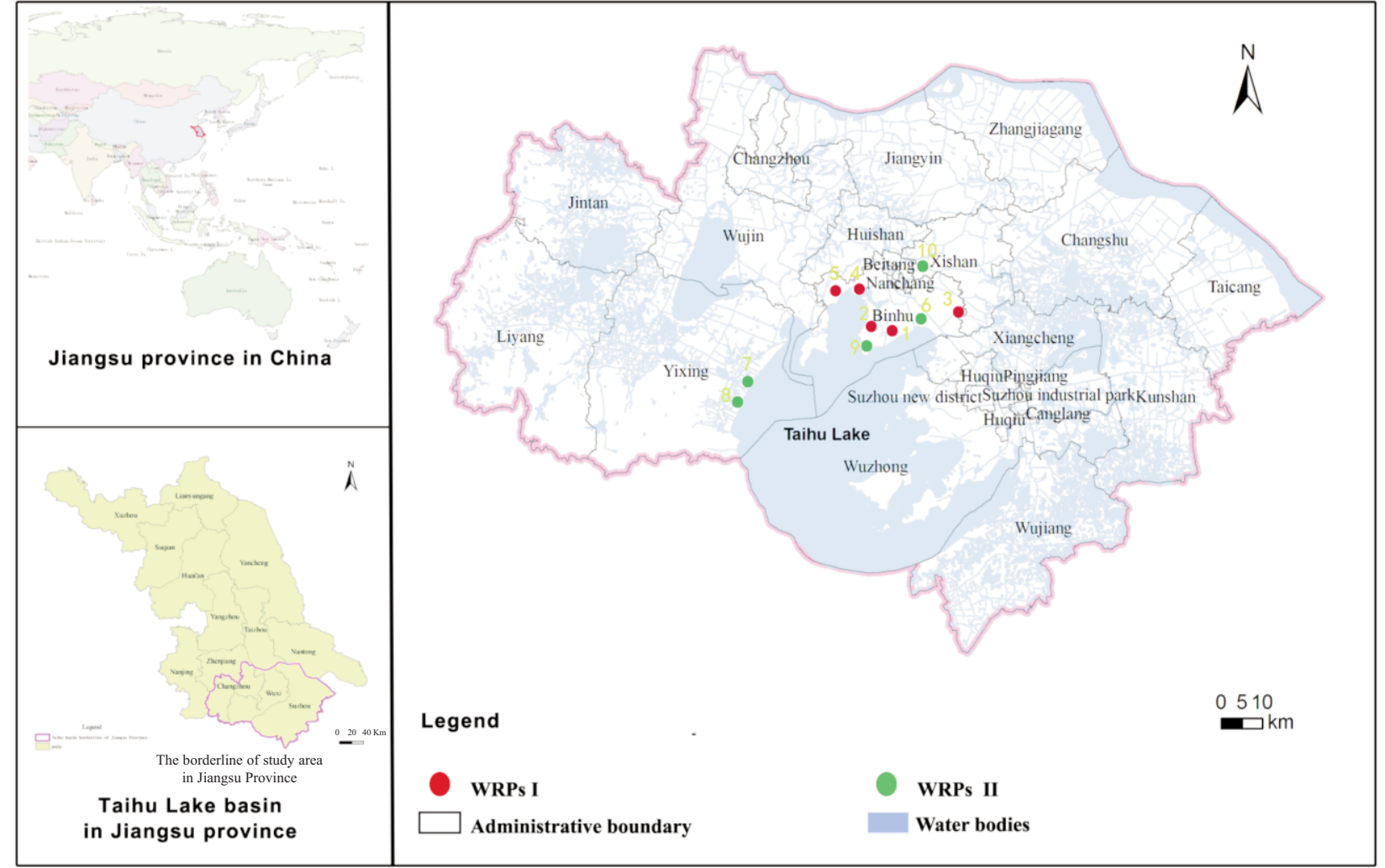

Fig. 1. Location of the surveyed area and WRPs of Taihu Lake basin.

1) Shangxianhe Wetland, 2) Changguangxi Wetland, 3) Lianghong Wetland, 4) Guansheshan Wetland, 5) Shibawan Lakeside Wetland, 6) Daxigang Estuary Wetland, 7) Taihu Lake Shore Wetland, 8) Dapugang Wetland, 9) Lianghewan Wetland, and 10) Jiulihe Wetland

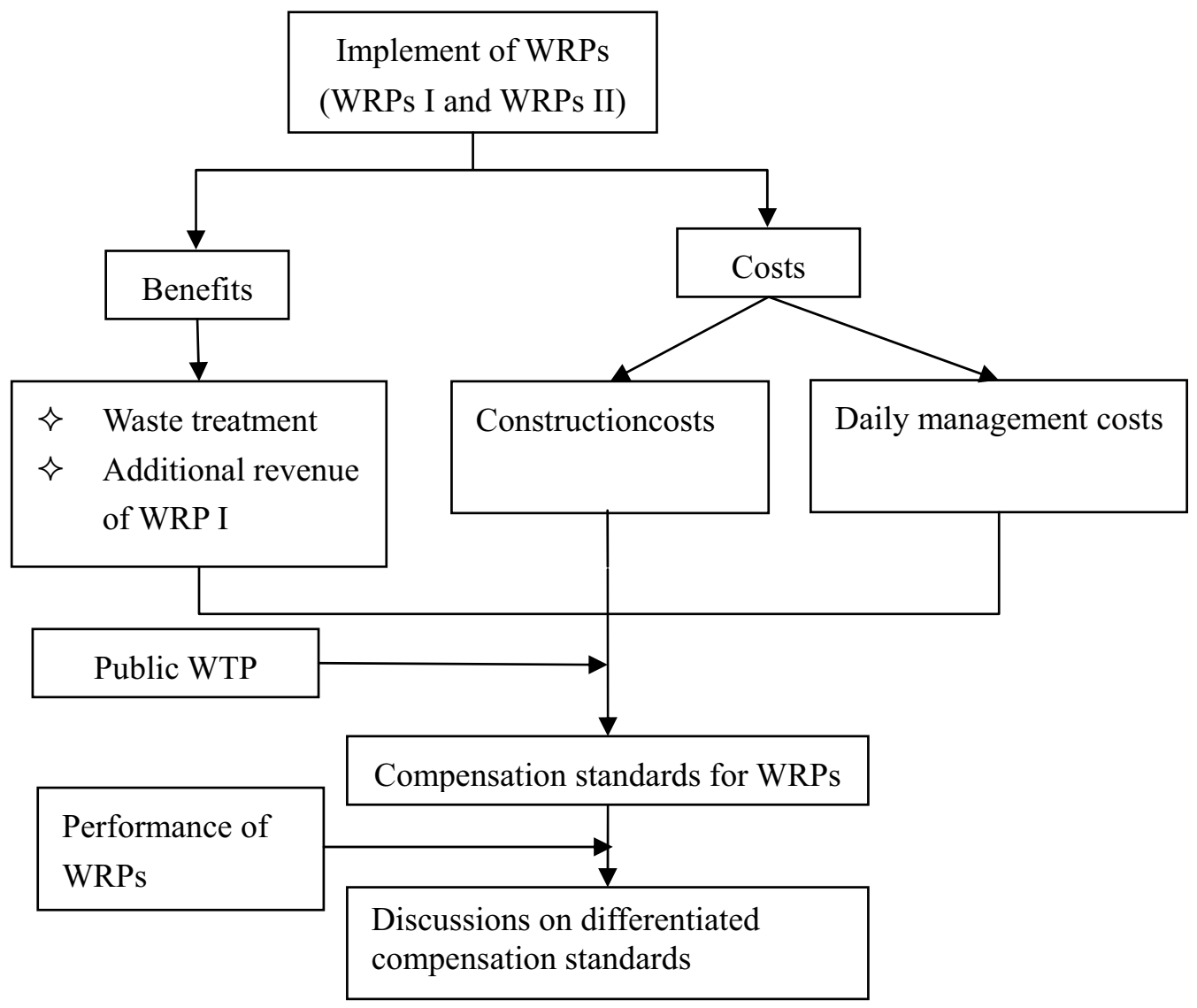

Fig. 2. The research framework. 


\section{Costs of WRPs}

The costs of WRPs can be grouped into two parts: construction $\left(C_{c\left(W R P_{s}\right)}\right)$ and daily management $\left(C_{m(\text { WRPs }}\right)$ costs. Construction cost is a one-off payment, while the daily management cost is the cost per year. Currently, $28.8 \%$ of the construction costs and the daily management expenses in most of the WRPs within the TLB are obtained from financial subsidies by governments [7]. These data for each of the WRPs were gathered from Taihu Lake's administration. According to Teng et al., construction cost was used to quantify the 20-year annuity of each WRP and WWTP [28].

\section{Environmental Benefit of WRPs}

Treatment wetland systems (TWS) are designed and constructed to utilize the natural processes involving wetland plants, soils, and their associated microbial assemblages to assist in removing significant amounts of suspended solids, organic matter, nitrogen, phosphorus, trace elements, and microorganisms contained in wastewater $[30,31]$. Pollutant removal rate $\left(R R_{i}, \mathrm{~kg} \cdot \mathrm{ha}^{-1} \cdot \mathrm{d}^{-1}\right)$ was defined as hydraulic loading rate multiplied by the difference in concentration between the influent and the effluent [32]. It is a more accurate way to present the treatment efficiencies of TWS because concentration and purification rates might alter due to precipitation, evaporation, and evapo-transpiration processes [33]. It was proved that the pollutant removal rate changed remarkably in the different TWSs [33]. Li et al. examined the effect of constructed wetlands in fish ponds along the Dianchi Lakeshore Region in China, and showed that the average removal rates for $\mathrm{COD}_{\text {cr }}$, TN, and TP were $12.9,1.1$, and $0.03 \mathrm{~kg} \cdot \mathrm{ha}^{-1} \cdot \mathrm{d}^{-1}[34]$, respectively. Wan et al. evaluated the effects of wetland systems and the control of rural non-point source pollution by constructing a multi-surface flow wetland in Poyang Lake, China [35]. The result showed that the average removal rates of $\mathrm{COD}_{\mathrm{cr}}$ and TN were 10.9 and $0.06 \mathrm{~kg} \cdot \mathrm{ha}^{-1} \cdot \mathrm{d}^{-1}$. Because of the limitations of data, we chose the three main pollutant indexes $\left(\mathrm{COD}_{\mathrm{cr}}, \mathrm{TN}\right.$, and $\left.\mathrm{TP}\right)$, and used the mean-value of the average removal rates of $\mathrm{COD}_{\mathrm{cr}}, \mathrm{TN}$, and $\mathrm{TP}$ in the above-mentioned empirical studies in China $\left(12 \mathrm{~kg} \cdot \mathrm{ha}^{-1} \cdot \mathrm{d}^{-1}\right.$, $1.0 \mathrm{~kg} \cdot \mathrm{ha}^{-1} \cdot \mathrm{d}^{-1}$, and $0.05 \mathrm{~kg} \cdot \mathrm{ha}^{-1} \cdot \mathrm{d}^{-1}$, respectively) as the removal amounts of pollutants per unit area per day.

For a given city, the pollutant discharge concentration $\left(C_{i}, \mathrm{mg} \cdot \mathrm{L}^{-1}\right)$ after dealing with the septic tank preliminary can be obtained by dividing pollutant discharge coefficient by sewage discharge coefficient:

$$
C_{i}=\frac{Q_{i}}{Q_{s}}
$$

...where $C_{i}$ is the discharge concentration of the ith pollutant (mg. $\left.\cdot \mathrm{L}^{-1}\right), Q_{i}$ is the discharge coefficient of the ith pollutant (mg. $\mathrm{d}^{-1}$ per person), and $Q_{s}$ is the discharge coefficient of sewage ( $\mathrm{Ld}^{-1}$ per person). The data of $Q_{i}$ and $Q_{s}$ of Wuxi City were provided by The First National Census of
Table 2. The discharge coefficient of pollutants and sewage in Wuxi City.

\begin{tabular}{|l|c|}
\hline \multicolumn{1}{|c|}{ Indexes } & Discharge coefficient \\
\hline COD $\left(\mathrm{mg} \cdot \mathrm{d}^{-1}\right.$ per person $)$ & 63 \\
\hline $\mathrm{TN}\left(\mathrm{mg} \cdot \mathrm{d}^{-1}\right.$ per person $)$ & 11,800 \\
\hline TP $\left(\mathrm{mg} \cdot \mathrm{d}^{-1}\right.$ per person $)$ & 980 \\
\hline Sewage $\left(\mathrm{L} \cdot \mathrm{d}^{-1}\right.$ per person $)$ & 185 \\
\hline
\end{tabular}

Pollution Sources of Urban Life Source Production and Emission Coefficient Manual (2008) (Table 2).

In Wuxi City, the ultimate effluent from the most urban WWTPs can meet the first A grade of National Discharge Standard (GB18918-2002) (COD ${ }_{\text {cr }} 50 \mathrm{mg} \cdot \mathrm{L}^{-1}$; TN $15 \mathrm{mg} \cdot \mathrm{L}^{-1}$; TP $\left.0.5 \mathrm{mg} \cdot \mathrm{L}^{-1}\right)$. The pollutant reduction $\left(R_{i}, \mathrm{t}^{-\mathrm{d}^{-1}}\right)$ can be estimated by the difference in the amount of pollutant between the influent and the effluent:

$$
R_{i}=\left(C_{i} \times S-S_{i} \times S\right) \times 10^{-9}
$$

...where $S$ is the operating scale of a WWTP $\left(t \cdot d^{-1}\right)$ and $S_{i}$ is the first A grade of National Discharge Standard (GB18918-2002) of the $i$ th pollutant $\left(\mathrm{mg} \cdot \mathrm{L}^{-1}\right)$.

In order to unify units to calculate the environmental benefits of WRPs, the relative area of WRPs was used to represent the pollutant reduction of WRPs by comparing with the pollutant reduction of urban WWTPs:

$$
\begin{gathered}
A=\frac{1}{n} \sum_{i=1}^{n}\left(\frac{R_{i}}{R R_{i}}\right) \\
\alpha=\frac{S}{A}
\end{gathered}
$$

...where $A$ is the average relative area of WRPs (ha), which represents that the pollutant reduction of WRPs with a certain area is the equal of the pollutant reduction of a WWTP with a certain operating scale in situ. For example, how many hectares of WRPs can be equated to the pollutants reduction of a 10,000 t/d WWTP built in a wetland project location, $\alpha$ is the coefficient that represents the fact that the pollutant reduction of WRP per ha is equal to the pollutant reduction of a WWTP with a certain scale $\left(\mathrm{t} \cdot \mathrm{ha}^{-1}\right), S$ is the operating scale of a WWTP $\left(\mathrm{t} \cdot \mathrm{d}^{-1} \cdot \mathrm{ha}\right)$, and $i$ is the number of pollutants.

The benefits of WRPs from treating waste can be estimated by comparing the construction costs and daily management costs of WRPs with WWTPs. The environmental benefits of WRPs are calculated by:

$$
\begin{gathered}
B_{c}=C_{c(W R P s)}-C_{c(W W T P s)}=C_{c(W R P s)}-C_{c(W W T P s)}, \\
B_{m}=C_{m\left(W R P_{s}\right)}-C_{m\left(W W T P_{s}\right)}= \\
C_{m\left(W R P_{s}\right)}-C_{m(W W T P s)} \times \boldsymbol{\alpha} \times 365
\end{gathered}
$$

...where $B_{c}$ is the environmental benefit of WRPs from the difference in the construction costs between the WRPs 
$\left.\left(C_{c(W R P s)}\right), \mathrm{USD} \cdot \mathrm{ha}^{-1}\right)$ and the WWTPs $\left(\mathrm{C}_{c(\text { WWTPS }}\right)\left(\mathrm{USD} \mathrm{ha}^{-1}\right)$, $B_{m}$ is the benefits of WRPs from the difference in the management costs between the WRPs $\left(C_{m(\text { WRPs })}\right)$ and the WWTPs $\left(C_{m(W W T P S)}\right)$ (USD·ha $\left.{ }^{-1} \cdot \mathrm{yr}^{-1}\right), C_{c(\text { WWTPs })}$ ' is the construction costs of WWTPs (USD· $t^{-1}$ ), and $\mathrm{C}_{\text {m(WWTPs) }}$ is the daily management costs of WWTPs $\left(\mathrm{USD} \cdot \mathrm{t}^{-1} \cdot \mathrm{d}^{-1}\right)$.

\section{Public WTP}

The major research data was collected through a household investigation with a standard questionnaire by using CVM, aimed to survey residents' WTP for approving the WPRs in Wuxi City to improve water quality.

The amount of samples was ascertained according to the total households in the research area. First, Binhu and Xishan Districts and Yixing City (a prefecture-level city in Wuxi City), which represent the geographic and socioeconomic conditions of Wuxi, were selected through purposeful sampling. Second, to ensure that the samples were representative of the population, a simple stratified random sampling technique was employed to select a sample of 400 households in the three areas. The number of households targeted in each area was proportional to the household density of that area (the total number of households divided by the total area). Each area was divided into a number of communities, according to the number of targeted households. Ten targeted households were randomly chosen in each community. All respondents were older than 18 years.

In the questionnaire, information was presented to the respondents so that they could gain a full understanding of the hypothetical situation, thus reducing the rejection rate and enabling respondents to reveal their values as accurately as possible [36]. In this scenario, the importance of wetlands in terms of providing ecosystem resources was emphasized, and the current situation of wetland contamination and degradation was described. To avoid bias, the interviewees were provided with a series of pictures and maps to show the initial achievements of WRPs and distinguish between WRPs I and II.

After pretesting by randomly selecting the 60 respondents, a three-page CV questionnaire was developed consisting of three main sections. The first section was devoted to collecting personal information about the respondents (income, sex, age, etc.). The second part contained attitudinal questions about the environment as well as the description of the environmental good under economic valuation. The third part consisted of questions related to WTP, aided by a payment card, asking about the maximum compensation as an annual payment: "In 2007, Taihu Lake experienced a blue-algae bloom event. A series of wetland restoration projects have been employed to restore ecological functions. The implementation of these programs incurs costs in the long term. Would your household be willing to pay annually during the next five years to support the WRPs I (WRPs II) or both in Taihu Lake?" (Note: respondents do not actually pay during the survey).

\section{(1) Yes (2) No}

"If you are willing to pay for wetland restoration, what is the maximum amount that your household would be willing to pay for WRPs I and II?" Respondents were provided with eight different offers on the basis of the pretest (RMB 5, 10, 20, 30, 50, 100, 200, and 500; US\$1.00 = RMB 6.52 in October 2011), from which they chose a single amount.

WTP values greater than zero were treated as a positive WTP. Respondents who chose to answer "unwillingness to pay" were treated as valid zero WTP. The latter were also asked a follow-up question to establish their reasons for rejection. To avoid any spurious emotions affecting responses, respondents were informed that the study was being conducted for academic purposes only. The questionnaire survey was conducted in October 2011 by a team of well-trained interviewers, and approximately 15 minutes were allotted to finish all questions.

\section{Additional Revenue of Wetland Parks}

In this study, the increase of land-transferring fees before $\left(F_{\text {before }}\right)$ and after $\left(F_{\text {after }}\right)$ implementation of the WRPs I was considered as the additional revenue of wetland parks. The additional revenue of wetland parks is calculated by:

$$
\begin{aligned}
& R_{e}=\left(F_{\text {after }}-F_{\text {before }}\right) \times a \\
& F_{\text {after }}=V_{\text {after }} \times S_{w} \times b \\
& F_{\text {before }}=V_{\text {before }} \times S_{w} \times b
\end{aligned}
$$

...where $R_{e}$ is additional revenue of wetland parks $\left(\mathrm{USD} \cdot \mathrm{ha}^{-1} \cdot \mathrm{yr}^{-1}\right), a$ is the ratio of the net income after deducting the costs (settlement fees, compensation for demolition and resettlement, construction costs of infrastructure, etc.) to the increase of land-transferring fees, $b$ is coefficient of land-transferring fees, $V_{\text {before }}$ and $V_{\text {after }}$ are the average land values before and after implementation of the WRPs I, and $S_{w}$ is the area of wetland parks. In China, the values of $a$ and $b$ are approximately 0.25 and 0.60 . The average surrounding land values before and after implementation of the WRPs I are $275.40 \cdot 10^{4} \mathrm{USD} \cdot \mathrm{ha}^{-1} \cdot \mathrm{yr}^{-1}$ and $995.65 \cdot 10^{4}$ USD $\cdot \mathrm{ha}^{-1} \cdot \mathrm{yr}^{-1}$ in Wuxi City. The land values in the surrounding areas of wetland parks were obtained from the local housing authority.

\section{Annual Value}

In the study, we compare the benefits and costs associated with WRPs using the annual values. Some estimates, such as the management costs of WRPs, environmental benefits of WRPs, and public WTP, are often expressed in terms of annuity. Benefits (e.g., land-transferring fees) and construction costs in lump-sum payments are converted into 20-year average annual values using the formula below: 
Table 3. Cost analysis of the studied WRPs.

\begin{tabular}{|c|c|c|c|c|}
\hline \multicolumn{2}{|r|}{ WRPs } & $\begin{array}{l}\text { Construction cost } \\
\quad\left(10^{4} \text { USD }\right)\end{array}$ & $\begin{array}{l}\text { Construction cost per ha-20 } \\
\text { years annuity }\left(10^{4} \mathrm{USD} / \mathrm{ha} \cdot \mathrm{yr}\right)\end{array}$ & $\begin{array}{l}\text { Daily management cost } \\
\quad\left(10^{4} \mathrm{USD} / \mathrm{ha} \cdot \mathrm{yr}\right)\end{array}$ \\
\hline \multirow{5}{*}{ WRPs I } & Shangxianhe Wetland & $8,902.30$ & 9.01 & 0.28 \\
\hline & Changguangxi Wetland & $5,774.54$ & 3.04 & 0.12 \\
\hline & Lianghong Wetland & $5,061.35$ & 4.55 & 0.10 \\
\hline & Guansheshan Wetland & $1,656.44$ & 3.49 & 0.12 \\
\hline & Shibawan Lakeside Wetland & $4,064.42$ & 1.23 & 0.08 \\
\hline \multicolumn{2}{|l|}{ Mean } & $5,091.81$ & 4.26 & 0.14 \\
\hline \multirow{5}{*}{ WRPs II } & Daxigang Estuary Wetland & 184.05 & 0.28 & 0.10 \\
\hline & Taihu Lake Shore Wetland & 149.39 & 0.16 & 0.03 \\
\hline & Dapugang Wetland & 32.06 & 0.17 & 0.15 \\
\hline & Lianghewan Wetland & 506.13 & 0.21 & 0.06 \\
\hline & Jiulihe Wetland & 153.37 & 0.26 & 0.14 \\
\hline \multicolumn{2}{|l|}{ Mean } & 205.00 & 0.22 & 0.10 \\
\hline
\end{tabular}

$$
P=\frac{L(1+r)^{n} r}{(1+r)^{n}-1}
$$

...where $P$ is the annuity of benefits or costs, $L$ is the associated lump-sum values, $r$ is the discounted rate, and $n$ is the number of years. The discounted rate was assumed to be 0.05 .

\section{Results and Discussion}

\section{Costs of WRPs}

The calculated costs of WRPs I and II were shown in Table 3. The costs were all converted to the 2011 U.S. dollar per hectare annually. The construction costs per hectare -20 years annuity of WRPs were between $0.16 \cdot 10^{4}$ and $9.01 \cdot 10^{4} \mathrm{USD}^{\mathrm{h}} \mathrm{ha}^{-1} \cdot \mathrm{yr}^{-1}$, and the daily management costs of WRPs were between $0.03 \cdot 10^{4}$ and $0.28 \cdot 10^{4} \mathrm{USD} \cdot \mathrm{ha}^{-1} \cdot \mathrm{yr}^{-1}$. It showed that the construction costs varied widely in different WRPs, while the daily management costs varied slightly in different WRPs. Moreover, the mean construction costs of WRPs I $\left(4.26 \cdot 10^{4} \mathrm{USD} \cdot \mathrm{ha}^{-1} \cdot \mathrm{yr}^{-1}\right)$ were much higher than those of WRPs II $\left(0.22 \cdot 10^{4} \mathrm{USD} \cdot \mathrm{ha}^{-1} \cdot \mathrm{yr}^{-1}\right)$, while there was little difference in mean daily management costs between WRPs I $\left(0.14 \cdot 10^{4} \mathrm{USD} \cdot \mathrm{ha}^{-1} \cdot \mathrm{yr}^{-1}\right)$ and II $\left(0.10 \cdot 10^{4}\right.$ $\left.\mathrm{USD}^{-1} \mathrm{ha}^{-1} \cdot \mathrm{yr}^{-1}\right)$.

Compared with the results of the Performance Evaluation of the First and Second Phrases Projects of Water Environment Comprehensive Treatment in TLB (PETLB), the construction costs of WRPs I in Wuxi City exceeded a given range in PETLB $\left(0.08 \cdot 10^{4} \sim 0.74 \cdot 10^{4}\right.$ USD $\left.\cdot \mathrm{ha}^{-1} \cdot \mathrm{yr}^{-1}\right)$, but the construction costs of WRPs II in Wuxi City are in accordance with the given range. The pos-
Table 4. The results of waste treatment of WRPs and WWTPs.

\begin{tabular}{|l|c|c|c|}
\hline \multicolumn{1}{|c|}{ Indexes } & $\mathrm{COD}_{\mathrm{cr}}$ & $\mathrm{TN}$ & $\mathrm{TP}$ \\
\hline $\begin{array}{l}\text { Pollutant removal rate of WRPs } \\
\left(\mathrm{kg} \cdot \mathrm{ha}^{-1} \cdot \mathrm{d}^{-1}\right)\end{array}$ & 20 & 1 & 0.05 \\
\hline $\begin{array}{l}\text { Pollutant emission concentration } \\
\left(\mathrm{mg} \cdot \mathrm{L}^{-1}\right)\end{array}$ & 340 & 64 & 5 \\
\hline Pollutant reduction in WWTP $\left(\mathrm{t} \cdot \mathrm{d}^{-1}\right)$ & 2.9 & 0.49 & 0.045 \\
\hline The relative area of WRPs (ha) & 242 & 490 & 900 \\
\hline
\end{tabular}

sible reason is that the WRPs I were not concluded in PETLB. The daily management costs of all WRPs in Wuxi City were consistent with that of PETLB evaluation $\left(0.04 \cdot 10^{4} \sim 0.27 \cdot 10^{4} \mathrm{USD} \cdot \mathrm{ha}^{-1} \cdot \mathrm{yr}^{-1}\right)$. The ECS calculated here by estimating the difference of the costs of WRPs and WTTPs, so we did not consider the opportunity cost.

\section{Environmental Benefit of WRPs}

Each waste treatment indicator for WRPs and WWTPs is summarized in Table 4. According to previous studies, we used the mean-value of the average removal rates of $\mathrm{COD}_{\text {cr }}$, TN and TP, $12 \mathrm{~kg} \cdot \mathrm{ha}^{-1} \cdot \mathrm{d}^{-1}, 1.0 \mathrm{~kg} \cdot \mathrm{ha}^{-1} \cdot \mathrm{d}^{-1}$, and 0.05 $\mathrm{kg} \cdot \mathrm{ha}^{-1} \cdot \mathrm{d}^{-1}$, respectively, as the removal amounts of pollutants per unit area per day in WRPs. In Wuxi, the discharge concentrations of $\mathrm{COD}_{\mathrm{cr}}, \mathrm{TN}$, and $\mathrm{TP}$ were $340 \mathrm{mg} \cdot \mathrm{L}^{-1}$, $64 \mathrm{mg} \cdot \mathrm{L}^{-1}$, and $5 \mathrm{mg} \cdot \mathrm{L}^{-1}$. Therefore, take a WWTP with $1 \cdot 10^{4} \mathrm{t} \cdot \mathrm{d}^{-1}$, for example, and the amounts of $\mathrm{COD}_{\mathrm{cr}}, \mathrm{TN}$, and TP of the influent are $3.4 \mathrm{t} \cdot \mathrm{d}^{-1}, 0.64 \mathrm{t} \cdot \mathrm{d}^{-1}$, and $0.05 \mathrm{t} \cdot \mathrm{d}^{-1}$, and the amounts of $\mathrm{COD}_{\mathrm{cr}}, \mathrm{TN}$, and $\mathrm{TP}$ of the effluent are $0.05 \mathrm{t} \cdot \mathrm{d}^{-1}, 0.15 \mathrm{t} \cdot \mathrm{d}^{-1}$, and $0.005 \mathrm{t} \cdot \mathrm{d}^{-1}$ in an urban WWTP which meet the first A grade of the National Discharge 
Table 5. Cost analysis of WRPs and WWTPs.

\begin{tabular}{|l|c|c|c|}
\hline \multicolumn{1}{|c|}{$\begin{array}{c}\text { Cost } \\
\left(\times 10^{4} \mathrm{USD}^{\mathrm{h}} \mathrm{ha}^{-1} \cdot \mathrm{yr}^{-1}\right)\end{array}$} & WRP I & WRP II & WWTP \\
\hline Mean construction cost & 4.26 & 0.22 & 0.04 \\
\hline Mean daily management cost & 0.14 & 0.10 & 0.20 \\
\hline
\end{tabular}

Standard (GB18918-2002). The reduction of $\mathrm{COD}_{\mathrm{cr}}$, TN, and TP are $2.9 \mathrm{t} \cdot \mathrm{d}^{-1}, 0.49 \mathrm{t} \cdot \mathrm{d}^{-1}$, and $0.045 \mathrm{t} \cdot \mathrm{d}^{-1}$, respectively. The relative area of WRPs, which represented the pollutant reduction of WRPs with a certain area, is the equal of the pollutant reduction of a WWTP with a certain scale in situ, obtained by calculating the ratio between the pollutant reduction in WWTPs and WRPs. As can be seen in Table 4, the $\mathrm{COD}_{\mathrm{cr}}$, TN, and TP reduction of $242 \mathrm{ha}, 490 \mathrm{ha}$, and 900 ha WRPs is the equal of the $\mathrm{COD}_{\mathrm{cr}}, \mathrm{TN}$, and TP reduction of a WWTP with $1 \cdot 10^{4} \mathrm{t} \cdot \mathrm{d}^{-1}$ in Wuxi City. Thus, the pollutant reduction of about 500 ha WRPs is the equal of the pollutant reduction of a WWTP with $1 \cdot 10^{4} \mathrm{t} \cdot \mathrm{d}^{-1}$ in Wuxi City, namely the pollutant reduction of 1 ha WRPs is the equal of the pollutant reduction of a WWTP with $20 \mathrm{t}^{-\mathrm{ha}^{-1}}$ $(\alpha=20)$.

The mean construction and daily management costs of WWTPs in Jiangsu Province in 2011 were 261 USD $t^{-1}$ and

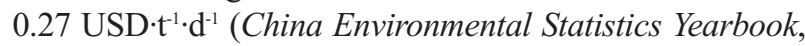
2012). In order to evaluate the environmental benefit of WRPs by comparing the costs of WRPs with the costs of WWTPs, all costs should be converted into a unified unit. Therefore, the mean construction and daily management costs of WWTPs in Wuxi City in 2011 were $0.04 \cdot 10^{4}$ USD $\cdot \mathrm{ha}^{-1} \cdot \mathrm{yr}^{-1}$ and $0.20 \cdot 10^{4} \mathrm{USD} \cdot \mathrm{ha}^{-1} \cdot \mathrm{yr}^{-1}$ (Table 5). As can be seen in Table 5, the costs of constructing a WRP I and WRP II with 1 ha were 4.26 and $0.22 \cdot 10^{4} \mathrm{USD} \cdot \mathrm{ha}^{-1} \cdot \mathrm{yr}^{-1}-4.22$ and $0.18 \cdot 10^{4}$ USD $\cdot h^{-1} \cdot \mathrm{yr}^{-1}$ higher than the WWTPs with comparable size in WRPs $\left(20 \mathrm{t}^{\cdot \mathrm{a}^{-1}}\right)$, while the costs of operating and managing a WRP I and WRP II with 1 ha were 0.14 and $0.10 \cdot 10^{4} \mathrm{USD} \cdot \mathrm{ha}^{-1} \cdot \mathrm{yr}^{-1}-0.06$ and $0.10 \cdot 10^{4} \mathrm{USD} \cdot \mathrm{ha}^{-1} \cdot \mathrm{yr}^{-1}$ lower than the WWTPs with comparable size in WRPs. For all costs, compared with a WWTP $\left(20\right.$ tha $\left.^{-1}\right)$, constructing a WRP I and WRP II with per ha in situ should pay more than 4.16 and $0.08 \cdot 10^{4} \mathrm{USD} \cdot \mathrm{ha}^{-1} \cdot \mathrm{yr}^{-1}$.

\section{Additional Revenue of Wetland Parks}

For WRPs I, in addition to their costs and environmental benefits, promoting land value and increasing revenues should be considered. According to the formula $(7,8,9)$, the result showed that additional revenue of constructing wetland parks by increasing land-transferring fees was $170.25 \cdot 10^{4} \mathrm{USD} \cdot \mathrm{ha}^{-1} \cdot \mathrm{yr}^{-1}$. Due to comparing with a WWTP $\left(20 \mathrm{t}^{-1} \mathrm{a}^{-1}\right)$, constructing a WRP I with per ha should pay more than $4.16 \cdot 10^{4} \mathrm{USD} \mathrm{ha}^{-1} \cdot \mathrm{yr}^{-1}$; it only needs to sell about 40 ha of land to recycle the costs. In general, it is possible that government can recover the costs after two years.

\section{Public WTP}

Of the 400 sampled respondents, $386(96.5 \%)$ answered the WTP questions. For the WRPs I, of 386 respondents, $261(67.6 \%)$ gave the amount of WTP that they were willing to pay when faced with a payment card question after the scenario description (WTP $>0$ ), which indicates that wetland parks conservation is accepted by most people. Of 386 respondents, 125 (32.4\%) hypothetically refused to pay any fee $(\mathrm{WTP}=0)$. Fig. 3 summarizes the statistics of the WTP responses in Wuxi. RMB 10, 50, and 100 were the most popular responses. We could get the mean WTP according to the numbers of samples, the WTP, and its ratio in the total sample: 6.46 USD $\cdot \mathrm{yr}^{-1}$ per household.

For the WRPs II, of 386 respondents, only 173 (44.8\%) were willing to pay (WTP $>0$ ). Fig. 4 summarizes the statistics of the WTP responses in Wuxi. RMB 10, 30, and 50 were the most popular responses. We could get the mean WTP according to the numbers of samples, the WTP, and its ratio in the total sample (3.47 USD·yr ${ }^{-1}$ per household).

During our survey, we found that the total number of households in the study area is 404,000 , and the mean areas of WRPs I and II were about 125 ha and 77 ha, respectively. Thus, the WTP for WRPs I was $2.09 \cdot 10^{4} \mathrm{USD}^{\mathrm{H}} \mathrm{ha}^{-1} \cdot \mathrm{yr}^{-1}$, which is slightly higher than the WTP for WRPs II of $1.82 \cdot 10^{4} \mathrm{USD}^{-} \cdot \mathrm{ha}^{-1} \cdot \mathrm{yr}^{-1}$.

\section{Compensation Standard for WRPs}

As mentioned above, compared with a WWTP $\left(20 \mathrm{t}^{-1} \mathrm{~h}^{-1}\right)$, constructing a WRP I and WRP II with per ha should pay

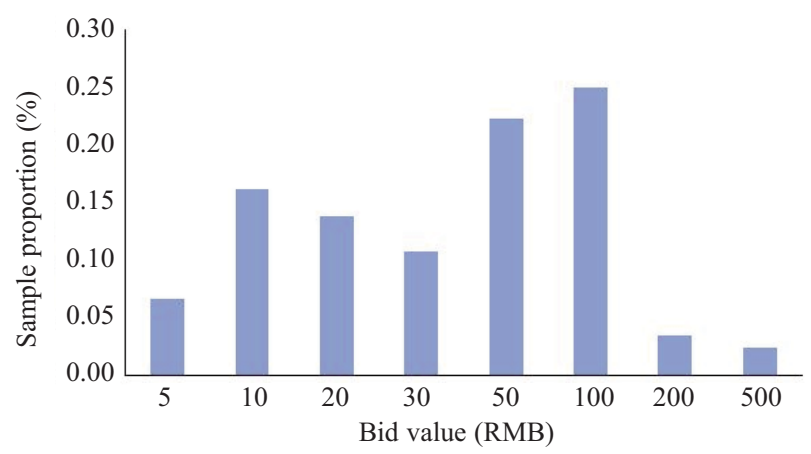

Fig. 3. The statistics of willing-to-pay bid amounts for WRPs I.

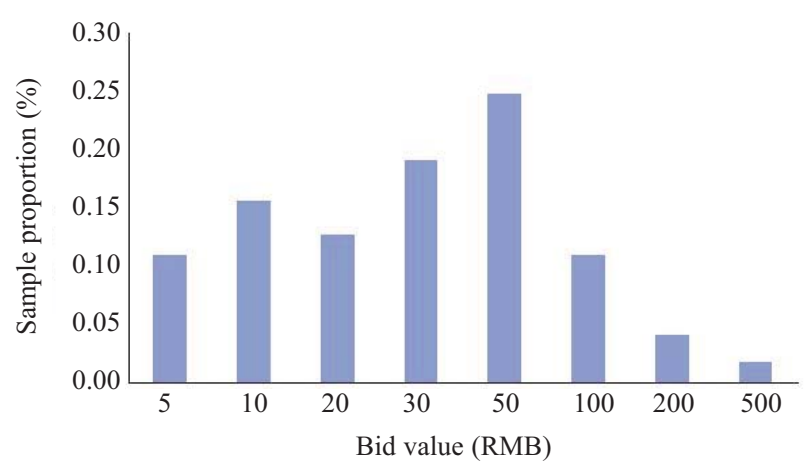

Fig. 4. The statistics of willing-to-pay bid amounts for WRPs II. 
more than 4.16 and $0.08 \cdot 10^{4} \mathrm{USD} \cdot \mathrm{ha}^{-1} \cdot \mathrm{yr}^{-1}$ in situ. If governments pay WRPs these extra fees as ecological compensation, it could almost ensure the construction and operation of WRPs in the future. Later, due to construction of WRPs I, the surrounding environment can be improved, and local infrastructure and public facilities also can be developed to absorb more visitors. Thus, the house price in a surrounding area of WRPs I will increase and the local governments will also gain benefits from these land-transferring fees. However, due to the WRPs II generally located in more remote locations, few people are around, there are mainly extensively planted reeds, and there is no sign for raising the surrounding house price by WRPs II construction in the next 10 years. Thus, for WRPs I, subsidies from the government can be according to the compensation standard of WRPs II.

If the public willingness to pay for supporting WRPs can be implemented in reality, the government need not pay extra compensation for WPRs. However, it is difficult to promote the public WTP in developing countries, especially in China [19]. Our survey found that the majority of respondents believe that the payment of taxes already covers these fees; the ecological compensation for wetland conservation should be paid by governments. Therefore, in the absence of public WTP, the government only needs to pay $0.08 \cdot 10^{4} \mathrm{USD} \cdot \mathrm{ha}^{-1} \cdot \mathrm{yr}^{-1}$ for WRPs I and II to ensure the construction and operation of WRPs. This standard is similar to the current subsidies standard of rice paddies in Suzhou City of Jiangsu Province, which is one of the earliest cities to implement wetland ecological compensation in China. This can prove that the ECS developed in the study presents a potentially effective route to wetland conservation. Moreover, in order to further reduce the fiscal pressure of government, it is in urgent need to promote and implement the public WTP, which can be more effective for wetland ecological compensation.

In this paper, the main purpose is to estimate the ECS of WRPs by comparing the costs and environmental benefits of the WRPs and WWTPs. Currently, the main facilities of treating domestic sewage and industrial sewage are still WWTPs, while WRPs are mainly used for ecological rehabilitation and restoration, and treating low-concentration sewage [37]. WRPs are not a substitute for WWTPs. Considering land limitation, there is not much area to construct WRPs, especially in urban areas [21].

\section{Implications of Differentiated Compensation Standards on Performance of WRPs}

Although the average financial subsidy by the governments for the first and second phrases of WRPs (2008-10) was approximately $0.055 \cdot 10^{4} \mathrm{USD} \cdot \mathrm{ha}^{-1}$, in our survey insufficient funds led to poor maintenance, low efficiency of operation, and operating deficits in many WRPs of TLB. The third and fourth phrases of WRPs were planned to be implemented in the long term (2015-20), the investments of which have been included in the financial budgets. Sun et al. strongly recommend modifying the current uniform
ECS by incorporating reward and punishment mechanisms according to the performance of WRPs [7]. Rao et al. suggested that future studies are needed to develop detailed rules implementing the compensation standard, including methods on fee collection (annual vs. lump-sum payments) [16]. In this study, due to the ECS being determined after evaluating WRP environmental performance every year, we took the method on subsidies annually rather than lumpsum payments. For example, the WRPs with poor performance will obtain less than the uniform ECS - even zero as punishments in the next year.

Environmental performance evaluation for WRPs is suggested according to the following methods:

$$
S C E P=\frac{\left(S_{C O D_{C r}}+S_{T N}+S_{T P}\right)}{3}
$$

...where SCEP is the score of comprehensive environmental performance; and $S_{C O D_{C r}}, S_{T N}$, and $S_{T P}$ are the scores of removal rates of pollutants $\left(\mathrm{COD}_{\mathrm{cr}}, \mathrm{TN}\right.$ and $\left.\mathrm{TP}\right)$, which is measured by the percentage of the change of pollutant concentration before and after constructing the WRPs accounting for the pollutant concentration before constructing the WRPs. For example, if the removal rates of $\mathrm{COD}_{\mathrm{cr}}$ for a WRP is $87 \%$, the $S_{C O D_{c r}}$ is 87 , whereas if the removal rates of $\mathrm{COD}_{\mathrm{cr}}$ is negative, the $S_{C O D_{c r}}$ is zero. The result of environmental performance for WRPs in Wuxi City can be seen in Table 6. Therefore, the differentiated ECS of WRPs in TLB is suggested according to the Table 7.

\section{Approaches for Increasing Capital Sources of Ecological Compensation}

As mentioned above, ecological compensation in China is largely relying on available government funds, which is insufficient, especially for governments that have been planning to build more WRPs in the future. Therefore, to overcome the problem it is necessary to increase capital sources to increase the standard of ecological compensation for WRPs. Actually, there were many ways to collect more capital. For example, at present most scholars determine eco-compensation standards according to the public payments for ecosystem services (PES) [38, 39]. Chang et al. pointed out that there is a need to implement PES as one form of ecological compensation to increase the revenue of ecological compensation [19]. However, in China the public environmental awareness and consciousness of ecological compensation are still relatively weak. In our questionnaire survey, over half of the respondents $(66.8 \%)$ had no, little, or basic knowledge about the ecological function of wetland projects. $43.0 \%$ claimed that it is moderately important to maintain the ecological environment of Wuxi. Thus, to ensure the sustainability of the WRPs there is a need to raise public awareness of the wetland ecosystem services, make people realize and understand their demand for wetland ecosystem services, and catch the public WTP to increase the revenue of ecological compensation. 
Table 6. Results of environmental performance for WRPs in Wuxi City.

\begin{tabular}{|c|c|c|c|c|c|}
\hline & \multirow{2}{*}{ WRPs } & \multicolumn{3}{|c|}{ Removal rates of pollutants (\%) } & \multirow{2}{*}{$\operatorname{SCEP}(0-100)$} \\
\hline & & $\mathrm{COD}_{\mathrm{Cr}}$ & $\mathrm{TN}$ & TP & \\
\hline \multirow{5}{*}{ WRP I } & Shangxianhe Wetland & 72.45 & 84.96 & 88.74 & 82 \\
\hline & Changguangxi Wetland & 42.53 & 94.24 & 80 & 72 \\
\hline & Lianghong Wetland & 60.54 & 90.13 & 85.65 & 78 \\
\hline & Guansheshan Wetland & 60.29 & 65.48 & 77.89 & 68 \\
\hline & Shibawan Lakeside Wetland & 18.09 & 49.44 & 33.33 & 34 \\
\hline \multirow{5}{*}{ WRP II } & Daxigang Estuary Wetland & 31.11 & 70 & 20 & 40 \\
\hline & Taihu Lake Shore Wetland & 13.75 & -2.36 & -25 & 0 \\
\hline & Dapugang Wetland & 20 & 25.17 & 12.65 & 19 \\
\hline & Lianghewan Wetland & -3.68 & 15.76 & -26.43 & 0 \\
\hline & Jiulihe Wetland & -7.62 & -18.35 & 5.74 & 0 \\
\hline
\end{tabular}

Data were obtained from the Environmental Quality Report of Wuxi City.

Table 7. The differentiated ecological compensation standards of WRPs in Taihu Lake Basin.

\begin{tabular}{|c|c|}
\hline $\begin{array}{c}\text { SCEP } \\
(0-100)\end{array}$ & $\begin{array}{l}\text { The increase and cut from baselines of ecological } \\
\text { compensation standards in the year after environ- } \\
\text { mental performance of WRPs (\%) }\end{array}$ \\
\hline$\geqq 80$ and $<100$ & 30 \\
\hline$\geqq 60$ and $<80$ & 0 \\
\hline$\geq 40$ and $<60$ & -10 \\
\hline$\geq 20$ and $<40$ & -20 \\
\hline$\geqq 0$ and $<20$ & -30 \\
\hline 0 & -40 \\
\hline
\end{tabular}

In addition, entrance fees are the main vehicle for protecting the ecological environment. It can help counteract the threat of inadequate funds for site maintenance and management, and may mitigate certain problems caused by a large number of visitors, such as overcrowding and disturbance [40, 41]. In Wuxi, most of the WRPs I are currently open access, resulting in low wetland tourist income [7]. To prepare guidelines for possible introduction entrance fees and efficient sustainable management of the WRPs I in TLB, according to our questionnaire survey, $49.18 \%$ of the respondents were willing to accept an entrance fee for entering Wetland Park for the purpose of wetland conservation. So ticketing - if necessary and possible - will contribute more to the increase in capital sources of ecological compensation for WRPs.

Finally, WRPs I may increase surrounding residential land values due to its tendency to create amenity values (e.g. aesthetic values and high-quality open space conservation within the landscape [42], whereas WRPs II often do not have this effect. Thus, it should pay attention to the landscape pattern of WRPs II, and promote vigorously WRPs to the public. The government could get more revenue through land transfer. However, building more housing around the wetlands will cause a large number of visitors to disturb the wetland ecosystem. So the effect of wetland conservation and ecological compensation will be better if governments integrate land transfer and other means of policy adjustment, such as entrance fees for entering wetlands.

\section{Conclusions}

Wetland restoration projects are vital to ecological conservation, environmental quality improvement, and human habitat environment improvement - especially in urban areas. Evaluations on the ecological compensation standard of wetlands in the previous studies often focus on opportunity costs, public WTPs, or farmers' compensation appeal [43-46]. However, a complex to evaluate ECS covering a wider aspect was established in this study. Compared with the research applying the ecosystem service evaluation method, the proposed new method in this study can more accuracy consider the costs and environmental benefits of WRPs, public WTPs, and the increase of surrounding housing prices of WRPs I.

The cost-benefit analysis was used to evaluate the ECS for WRPs. In addition to the same index of cost-benefit for WRPs I and II, the effect of increasing housing prices in surrounding areas of wetland is an additional consideration for WRPs I (Fig. 1). By comparing the costs of WWTPs with the costs of WRPs and using the CVM method, the environmental benefit of WRPs and public WTP were obtained. This framework was applied to 10 WRPs within Taihu Lake Basin, China. The results showed that the WTP for WRPs I and II were 2.09·10 USD $\cdot \mathrm{ha}^{-1} \cdot \mathrm{yr}^{-1}$ and $1.82 \cdot 10^{4}$ USD $\cdot \mathrm{ha}^{-1} \cdot \mathrm{yr}^{-1}$. Considering the land-transferring fees of the 
surrounding area of WRPs I, WRP I subsidies from the government can be calculated according to the compensation standard of WRPs II. Thus, if the public willing to pay for supporting WRPs can be implemented in reality, the government need not to pay extra compensation for WRPs. In the absence of public WTPs, the government only needs to pay I $0.08 \cdot 10^{4} \mathrm{USD} \cdot \mathrm{ha}^{-1} \cdot \mathrm{yr}^{-1}$ for WRPs I and II to ensure the construction and operation of WRPs.

With the help of ECS established in this study, decision makers can obtain a differentiated compensation standard by incorporating reward and punishment mechanisms that can be formulated to enable the greatest returns on investment in WRPs. By analyzing the costs and benefits of WRPs, the approaches for increasing capital sources of ecological compensation for WRPs were recommended, including improvement in public awareness of the wetland ecosystem services, capturing the public, ticketing wetland park entrances, land-transferring fees, and the integration of the above methods.

It should be emphasized that his proposed framework is not only applicable to this case study, but also suitable to be applied to conduct ECS for wetland restorations in other areas. Note that the data of pollutant removal rates of WRPs and costs of WWTPs represent only a simple rendering of the results of wetland restorations, and future research needs to be more accurately measured.

\section{Acknowledgements}

This work was supported by Taihu Lake Water Pollution Control of Jiangsu Province (TH2010301) and the State Key Laboratory of Pollution Control and Resources Reuse, Natural Science Foundation of Jiangsu Province (BK2011404).

\section{References}

1. COSTANZA R., D'ARGE R., DE GROOT R., FARBER S., GRASSO M., HANNON B., LIMBURG K., NAEEM S., O'NEILL R.V., PARUELO J. The value of the world's ecosystemservices and natural capital. Nature 387, (6630), 253, 1997.

2. DUFFY W.G., KAHARA S.N. Wetland ecosystem services in California's Central Valley and implications for the Wetland Reserve Program. Ecol. Appl. 21, (sp1), 18, 2011.

3. VERHOEVEN J.T. Wetlands in Europe: perspectives for restoration of a lost paradise. Ecol. Eng. 66, 6, 2014.

4. CAI Y.B., ZHANG H., PAN W.B., CHEN Y.H., WANG X.R. Land use pattern, socio-economic development, and assessment of their impacts on ecosystem service value: study on natural wetlands distribution area (NWDA) in Fuzhou city, southeastern China. Environ. Monit. Assess. 185, (6), 5111, 2013.

5. LI Y.F., SHI Y.Q., QURESHI S., BRUNS A., ZHU X.D. Applying the concept of spatial resilience to socio-ecological systems in the urban wetland interface. Ecological Indicators 42, 135, 2014.
6. GUO T., ZHANG X., CHENG T. Evaluation of wetland restoration project based on SD: a case study on Qilihai Wetland in Tianjin. Procedia Environmental Sciences 10, 2587, 2011.

7. SUN X., XIONG S., ZHU X.J., ZHU X.D., LI Y.F., LI B.L. A new indices system for evaluating ecological-economicsocial performances of wetland restorations and its application to Taihu Lake Basin, China. Ecol. Model. 295, 216, 2015.

8. HAN F., YANG Z.P., WANG H., XU X.L. Estimating willingness to pay for environment conservation: a contingent valuation study of Kanas Nature Reserve, Xinjiang, China. Environ. Monit. Assess. 180, 451, 2011.

9. HAN M., CUI J.H., HAO Z., WANG Y., WANG R.Q. Ecocompensation of wetlands in Yellow River Delta of Shandong Province, China. Chinese Geographical Science 22, (1), 119, 2012 [In Chinese].

10. LIU M.C., XIONG Y., YUAN Z., MIN Q. W., SUN Y. H., FULLER A.M. Standards of ecological compensation for traditional eco-agriculture: Taking rice-fish system in Hani terrace as an example. Journal of Mountain Science 11, (4), 1049, 2014.

11. BAYLIS K., PEPLOW S., RAUSSER G., SIMON L. Agrienvironmental policies in the EU and United States: A comparison. Ecol. Econ. 65, (4), 753, 2008.

12. MACMILLAN D., HANLEY N., DAW M. Costs and benefits of wild goose conservation in Scotland. Biol. Conserv. 119, (4), 475, 2004.

13. KANAYO O., EZEBUILO U., MAURICE O. Estimating the Willingness to Pay for Water Services in Nsukka Area of South-Eastern Nigeria Using Contingent Valuation Method (CVM): Implications for Sustainable Development. J. Hum. Ecol. 41, (2), 93, 2013.

14. XIE R.R., PANG Y., LI Z., ZHANG N.H., HU F.J. EcoCompensation in Multi-District River Networks in North Jiangsu, China. Environmental Management 51, (4), 874, 2013 [In Chinese].

15. XIONG Y., WANG K.L. Eco-compensation effects of the wetland recovery in Dongting Lake area. Journal of Geographical Sciences 20, (3), 389, 2010.

16. RAO H., LIN C., KONG H., JIN D., PENG B.R. Ecological damage compensation for coastal sea area uses. Ecological Indicators 38, 149, 2014.

17. GARDNER R.C., ZEDLER J., REDMOND A., TURNER R.E. Compensating for wetland losses under the Clean Water Act (redux): Evaluating the federal compensatory mitigation regulation. Stetson L. Rev. 38, 213, 2008.

18. REISS K.C., HERNANDEZ E., BROWN M.T. Application of the landscape development intensity (LDI) index in wetland mitigation banking. Ecol. Model. 271, 83, 2014.

19. CHANG I.S., WU J., YANG Y.X., SHI M.M., LI X.C. Ecological compensation for natural resource utilisation in China. Journal of Environmental Planning and Management 57, (2), 273, 2014.

20. QIN B.Q., ZHU G.W., GAO G., ZHANG Y.L., LI W., PAERL H.W., CARMICHAEL W.W. A drinking water crisis in Lake Taihu, China: linkage to climatic variability and lake management. Environ. Manage. 45, 105, 2010.

21. LI L., LI Y., BISWAS D.K., NIAN Y.G., JIANG G.M. Potential of constructed wetlands in treating the eutrophic water: evidence from Taihu Lake of China. Bioresource Technol. 99, (6), 1656, 2008.

22. HUANG W.Y., XU G., WU Q.L., QIN B.Q. Pollution and eutrophication. In: Qin BQ (Ed) Lake Taihu, China, dynamics and environmental change. Springer Science+Business Media B.V. 23, 2008. 
23. GUO L. Doing battle with the green monster of Taihu Lake. Science 317, 1166, 2007.

24. YANG M., YU J.W., LI Z.L., GUO Z.H., BURCH M. Taihu Lake not to blame for Wuxi's woes. Science 319, $158,2008$.

25. WÜNSCHER T., ENGEL S., WUNDER S. Spatial targeting of payments for environmental services: a tool for boosting conservation benefits. Ecol. Econ. 65, (4), 822, 2008.

26. HU L., HU W.P., DENG J.C., LI Q.Q., GAO F., ZHU J.G., HAN T. Nutrient removal in wetlands with different macrophyte structures in eastern Lake Taihu, China. Ecol. Eng. 36, (12), 1725, 2010.

27. MITSCH W.J., ZHANG L., WALETZKO E., BERNAL B. Validation of the ecosystem services of created wetlands: Two decades of plant succession, nutrient retention, and carbon sequestration in experimental riverine marshes. Ecol. Eng. 72, 1, 2014.

28. TENG C.J., LEU S.Y., KO C.H., FAN C., SHEU Y.S., HU H.Y. Economic and environmental analysis of using constructed riparian wetlands to support urbanized municipal wastewater treatment. Ecol. Eng. 44, 249, 2012.

29. KAZA N., BENDOR T.K. The land value impacts of wetland restoration. J. Environ. Manage. 127, 289, 2013.

30. CHENG X.Y., LIANG M.Q., CHEN W.Y., LIU X.C., CHEN Z.H. Growth and contaminant removal effect of several plants in constructed wetlands. J. Integr. Plant Biol. 51, (3), 325, 2009.

31. VYMAZAL J. Constructed wetlands for wastewater treatment: five decades of experience. Environ. Sci. Technol. 45, (1), 61, 2011.

32. LIN Y.F., JING S.R., LEE D.Y., WANG T.W. Nutrient removal from aquaculture wastewater using a constructed wetlands system. Aquaculture 209, (1), 169, 2002.

33. SHARMA P.K., TAKASHI I., KATO K., IETSUGU H., TOMITA K., NAGASAWA T. Effects of load fluctuations on treatment potential of a hybrid sub-surface flow constructed wetland treating milking parlor waste water. Ecol. Eng. 57, 216, 2013.

34. LI Y.X., XU X.M., HONG C.H., HE J., LI Z.X., CHEN Y.B., LI Z.J. The applicationstudy on surface constructed wetlands for non-point source pollution control at the
Dianchi Lakeshore Region. Journal of Agro-Environment Science 28, (10), 2155, 2009 [In Chinese].

35. WAN J.B., LAN X.Y., TAN A.P. Application of multi-surface flow constructed wetland to rural non-point source pollution control in Poyang Lake Region. Bulletin of Soil and Water Conservation 30, (5), 118, 2010.

36. LEE C.K., HAN S.Y. Estimating the use and preservation values of national parks' tourism resources using a contingent valuation method. Tourism Manage. 23, 531, 2002.

37. KING S.L., TWEDT D.J., WILSON R.R. The role of the Wetland Reserve Program in conservation efforts in the Mississippi River Alluvial Valley. Wildlife Soc. B. 34, (4), 914, 2006.

38. KWAK S.J., YOO S.H., LEE C.K. Valuation of the Woopo Wetland in Korea: a contingent valuation study. Environment and Development Economics 12, (02), 323, 2007.

39. SPASH C.L. Ecosystems, contingent valuation and ethics: the case of wetland re-creation. Ecol. Econ. 34, (2), 195, 2000.

40. REYNISDOTTIR M., SONG H., AGRUSA J. Willingness to pay entrance fees to natural attractions: An Icelandic case study. Tourism Manage. 29, (6), 1076, 2008.

41. WANG P.W., JIA J.B. Tourists' willingness to pay for biodiversity conservation and environment protection, Dalai Lake protected area: Implications for entrance fee and sustainable management. Ocean Coast. Manage. 62, 24, 2012.

42. MITSCH W.J., GOSSELINK J.G. Wetlands, third ed. Van Nostrand Reinhold, NewYork, NY, 2000.

43. XIONG Y., WANG K.L. Study on eco-compensation of returning land to lake: A case of Dongting Lake areas. Wetland Science I, (2), 86, 2003 [In Chinese].

44. LANTZ V., BOXALL P. C., KENNEDY M., WILSON J. The valuation of wetland conservation in an urban/peri urban watershed. Regional Environmental Change 13, (5), 939, 2013.

45. PETROLIA D.R., KIM T.G. Preventing land loss in coastal Louisiana: estimates of WTP and WTA. J. Environ. Manage. 92, 859, 2011.

46. WATTAGE P., MARDLE S. Total economic value of wetland conservation in Sri Lanka: identifying use and non-use values. Wetlands Ecology and Management 16, 359, 2008. 